\title{
The Role of Goal Orientations and the Use of Digital Media in the Classroom Quality in the Final Grades of Elementary Education
}

Antonio Jurčev¹, Tomislav Topolovčan² and Nevenka Maras²

${ }^{1}$ A. G. Matoš Elementary school

2University of Zagreb, Faculty of Teacher Education

\section{Abstract}

The aim of the study was to examine the characteristics and predictor role of goal orientations in learning, the level of digital media equipment in schools and the use of digital media in classroom (teaching) quality in lower secondary education (ISCED level 2). The study included seventh and eighth grade students $(N=432)$ of elementary schools in the City of Zagreb and Split-Dalmatia County. Besides demographic characteristics of students and the level of digital media equipment in schools, the data were collected by the Goal orientation questionnaire (CSRL), the Technology implementation questionnaire (TIQ), and Student perception of classroom quality questionnaire (SPOCQ). It was concluded that, overall, demographic characteristics of students, their goal orientations, the level of digital media equipment in schools and motivation for the use of digital media are significant predictors of student perception of classroom quality, with the highest percentage of variance explained by goal orientations and with emphasis on learning orientation. In this regard, it is evident that for the teaching quality in the digital age, goal orientation, i.e., motivation for learning, is more significant than the use of digital media. Comparison with theoretical postulates and implications of these results are explained in this paper.

Key words: classroom quality; digital media; elementary school; goal orientations; students.

\section{Introduction}

The euphoria regarding the use of digital media in teaching in terms of raising its quality, and therefore the efficiency of achieving the desirable learning outcomes, which 
occurred about forty years ago, has been neutralized (Tamim et al., 2011; Timmerman \& Kruepke, 2006). It appears that the use of digital media is not the only factor which increases teaching and learning quality (Tamim et al., 2011). The use of (digital) media is merely one of many correlated factors which can be predictors of classroom quality ${ }^{1}$ and increase the probability of desirable learning outcomes in students (Dillon \& Gabbard, 1998; Tamim et al., 2011). In this regard, investigations have shown that students' individual characteristics, such as cognitive and psychomotor abilities for learning, motivation for learning, level of prior knowledge, parents' socio-economic status, and competence and motivation for using digital media, are important for increasing the level of desirable learning outcomes. Moreover, the level of digital media equipment in schools, teachers' qualifications, programme level, teaching goals and learning contents, as well as the evaluation methods, are also important, whereas one of the most important factors is the didactic organisation of learning activities, i.e., didactic arrangement with origins in (socio)constructivist paradigm of classroom teaching (Hattie, 2009; Rodek, 2011). This was also the theoretical basis for this study. Namely, the researchers wanted to examine what part of variance of classroom quality, as defined by Gentry and her colleagues (Chae \& Gentry, 2007, 2011; Gentry \& Gable, 2001; Gentry \& Owen, 2004; Gentry, Gable, \& Rizza, 2002), was explained by particular demographic characteristics, the level of digital media equipment of schools, the reasons (motivation) for their use based on the expectancy-value theory (e.g., Eccles, 2005; Wozney, Venkatesh \& Abrami, 2006), and by goal orientations (Niemivirta, 1996, 1998).

Classroom (teaching) quality can be studied from different aspects (students, teachers, parents, local community, educational policies), however, it is extremely important to realize in what way students perceive classroom quality, i.e., different teaching activities, instruction, and curriculum, keeping in mind that students comprehension of classroom quality can greatly differ from that of teachers. Precisely with this goal in mind, the Student perception of classroom quality - SPOCQ questionnaire (Gentry \& Owen, 2004) was constructed. By keeping students' perception in consideration, teachers and school expert teams can improve classroom quality and meet students' needs, which ultimately has a positive effect on students' motivation and achievement (Chae \& Gentry, 2011; Gentry \& Owen, 2004). The questionnaire is composed of different constructs which are related to learning and motivation. SPOCQ is composed of students' perceptions of classroom (teaching) activities regarding the appeal of teaching, challenge of teaching activities, choice of work activities, meaningfulness of the contents being learned, and academic self-efficacy (Chae \& Gentry, 2011). Regarding this instrument, the results showed that gifted

\footnotetext{
${ }^{1}$ In this article the term "classroom quality" is used, as the original term in literature, as well as in the research scale (Gentry \& Chae, 2007, 2011). The term "classroom quality" encompasses the organization of common (classroom) teaching activities (by teachers) and learning activities (by students), with the purpose of achieving learning outcomes.
} 
students had a positive perception of classroom quality, but there were some cultural and national differences (Chae \& Gentry, 2011). Gender differences were found in the perception of classroom quality dimensions (using an instrument lacking the Appeal dimension), i.e., girls had a more positive perception of different classroom activities (Gentry et al., 2002). However, in Croatia, homogenous results have not been found, meaning that gender differences between students existed in some cases, and lacked in others (Matijević, Drljača, \& Topolovčan, 2016; Matijević, Opić, \& Rajić, 2015). Students in upper secondary vocational schools had different perceptions of certain dimensions in comparison with their peers attending grammar schools, although the overall sample gave a negative or neutral assessment of classroom quality (Matijević et al., 2015). On the other hand, there were some differences in certain dimensions between lower and upper secondary schools regarding art classes and the final grade (Matijević et al., 2016). Intrinsic learning environment (Hattie, 2009), such as certain types of motivation for learning, was also shown to be important for classroom quality. The learning process and learning outcomes in school environment have been extensively investigated by educational and developmental psychologists, and with the aim of explaining them, the goal orientation model was developed by Pintrich \& Schunk (1996, as cited in Stanišak Pilatuš, Jurčec, \& Rijavec, 2012). Goal orientations are a motivational concept, intrinsic or extrinsic, through which students interpret situations in which they are oriented towards mastering a task or mastering a performance. Motivational mindset affects the types of goals, outcomes and activities students seek to attain or avoid (Niemivirta, 2002; Tuominen-Soini, Salmela-Aro, \& Niemivirta, 2008). Regarding their motivational profile, several different types of students can be found in literature. Thus, groups that have a dominant goal orientation - learning-oriented, performance-oriented, and avoidance-oriented - are anticipated (Niemivirta, 1998, 2002b; Roeser, Strobel, \& Quihuis, 2002). From the three abovementioned aspects of goal orientations, in relation to students of different levels of education, it is evident that students learn because they want to become experts in some area (Dweck, 1986), to demonstrate their superior ability, or to learn how to achieve the best results with least effort. Furthermore, gender differences indicate that girls are more learningand performance-oriented, whereas boys are more performance- and avoidanceoriented (Thorkildsen \& Nicholls, 1998). Boys are more likely to adopt work-avoidance goals (Rijavec \& Brdar, 2002), whereas there have been some studies that show no differences between boys and girls regarding performance orientation (Niemivirta, 1996). Students with different motivational profiles prefer different approaches to learning and instruction, which clearly indicates that the educational system is facing new challenges, one of which is the implementation of digital media in schools. In addition to students' individual characteristics, in terms of their intrinsic learning environment, i.e., goal orientations, contemporary and future classroom teaching cannot be planned outside the framework of digital media and the level of digital media equipment in schools (Tamim et al., 2011; Topolovčan et al., 2017). 
The use of digital media can be of great importance for learning (Bereiter, 2002), but can also promote the culture of learning (Coley, Cradler, \& Engel, 1977), which is the reason why they should be integrated through curricular planning. On the other hand, the level of digital media equipment in school varies depending on whether it is an elementary or secondary school, a city school or a village school, but also, students' assessment regarding this issue depends on their gender, grades, and the class they attend (Topolovčan et al., 2017). Moreover, students' assessment regarding the level of digital media equipment in schools is lower than the teachers' (Topolovčan et al., 2017). When implementing digital media, educational policies and strategies of their implementation in schools should be coordinated with "primary education, and lower and upper secondary education teachers' acquisition of new didactic literacy" (Matijević, Topolovčan, \& Rajić, 2017, p. 603). The implementation of digital media is imposed as a challenge, which is the reason why the expectancy-value theory developed by Eccles and her colleagues (e.g., Eccles, 2005; Eccles \& Wigfield, 1995; Wigfield \& Eccles, 2000), as a model for understanding and predicting behaviour in the innovation implementation process, plays a significant role. Originally, the expectancy-value theory describes a process of students making choices during their schooling. Primary motivation for academic choices is the expectancy of one's own success and task value (Eccles, 2005; Wigfield \& Eccles, 2000). The model consists of two mainly different constructs: a) expectancy, which refers to success or conviction about abilities, and b) value, which refers to intrinsic value, i.e., subjective value and achievement value. The latter can sometimes also include a third segment - cost (Eccles, 2005), which refers to the effort that must be put in a certain task (Eccles \& Wigfield, 1995). Based on the expectancy-value theory (Eccles et al., 1983), Wozney, Venkatesh, and Abrami (2006) constructed the Technology implementation questionnaire. The application of this instrument among Croatian students (Topolovčan et al., 2017) showed that students gave a positive assessment of the value of using digital media in teaching, had slightly lower expectancy, and believed the use of digital media did not require additional effort on their part. Moreover, students' assessment regarding all three dimensions of implementation (use) of media in teaching activities were more positive than the teachers' assessment. Furthermore, in certain dimensions of digital media implementation there were differences regarding gender, type of school and class they attended (Topolovčan et al., 2017). It is important to point out that the use (implementation) of digital media in teaching activities was positively correlated with higher computer self-efficacy and with elements of constructivist learning (Topolovčan et al., 2017), but it was a more significant predictor of constructivist learning as compared to the level of computer self-efficacy and possession of certain digital media among students (Topolovčan \& Matijević, 2016). Considering the abovementioned, it is assumed that classroom quality, students' goal orientations and digital media implementation are correlated, i.e., that goal orientations and the use of digital media can be predictors of classroom quality. However, it is not known to what extent. 


\section{Methodology}

Aim

The aim of the study was to examine the characteristics and predictor role of students' demographic characteristics, their goal orientations, the level of digital media equipment in schools, and the use of digital media in classroom quality in the final grades of lower secondary education.

\section{Sample}

The study involved elementary school students $(N=432)$ of lower secondary education (ISCED, level 2) in the City of Zagreb and Split-Dalmatia County. The sample included 220 (50.9\%) students from the City of Zagreb, and 212 (49.1\%) students from Split-Dalmatia County. Regarding gender, 200 (46.3\%) participants were boys, and $232(53.7 \%)$ were girls. There were 213 (49.3\%) students in the seventh grade, and 219 (50.7\%) students in the eighth grade. Of the total sample, 406 (94\%) students lived in a city, whereas $26(6 \%)$ students lived in a village. Regarding their average final grade, 87 (20.1\%) students were good, 149 (34.5\%) students were very good, and 196 (45.4\%) students were excellent at the end of the previous school year.

\section{Instruments}

In addition to demographic data (gender, class, school location, county, and final grade), data on the level of digital media equipment in schools and data on selfassessment of classroom quality and goal orientations were collected.

The demographic data referred to gender (male/female), class (seventh/eight), school location (city/village), county/city (the City of Zagreb/Split-Dalmatia County), and final grade at the end of the previous school year (from insufficient to excellent). Data on the level of digital media equipment in schools referred to computers, the Internet, computer programs, projectors, smartboards, tablets, and social media, and it was measured on a three-point scale (1 - completely unequipped; 2 - somewhat equipped; 3 - fully equipped).

For self-assessment of classroom quality, the Goal orientation questionnaire was used, which consists of fifteen manifest statements assessed on a 5-point Likert scale ( $1=$ Strongly disagree, $2=$ Disagree, $3=$ Undecided, $4=$ Agree, $5=$ Strongly agree). Manifest statements form three factors - five statements each. The Performance orientation factor is oriented towards student's achievement by which he/she proves himself/ herself to others ("I am particularly satisfied when I do better in school than others"). The Avoidance orientation factor examines student's avoidance of effort, i.e., achieving a pass grade by putting in the least effort ("I try to do my schoolwork with as little effort as possible."). The Learning orientation factor is oriented towards learning something new, solving problems and gaining knowledge as a value in itself ("The most important goal for me in school is to acquire new knowledge."). As this questionnaire has already been used in the Republic of Croatia, the existing translation was used with the 
authors' permission (Stanišak Pilatuš, Jurčec, \& Rijavec, 2013). Exploratory factor analysis (PCA) with oblimin rotation, saturation higher than .40, and eigenvalue greater than $1(\mathrm{PCA})(\mathrm{KMO}=.805$; Bartlett's test of sphericity was significant, $\chi 2=$ $2913.198 ; \mathrm{p}=.000)$ yielded three factors, which collectively accounted for $60.1 \%$ of the total variance. The three obtained factors almost completely replicated the original factor structure. Namely, the first factor had loadings on five statements of Learning orientation (the eigenvalue was 4.57 , and the explained variance was $30.47 \%$ ). The second factor had loadings on five statements of Avoidance orientation (the eigenvalue was 2.88 , and the explained variance was $19.21 \%$ ), while the third factor had loadings on four statements of Performance orientation (the eigenvalue was 1.56, and the explained variance was $10.42 \%)$. One statement of Performance orientation did not have significant loading. Therefore, it was justified to use the original factor structure of the questionnaire, which was also confirmed by satisfactory reliability (Table 1).

Data regarding the use of digital media in the teaching were collected using the Technology implementation questionnaire constructed by Wozney, Venkatesh, and Abrami (2006), with the purpose of examining the reasons, i.e., motivation for using digital technology and media in the classroom. The questionnaire consists of thirtythree manifest statements on a 5-point Likert scale $(1=$ Strongly disagree, $2=$ Disagree, $3=$ Neutral, $4=$ Agree, 5 = Strongly agree). In this study, a 5-point scale was used, even though the original is a 6-point scale, as this way a neutral option was given. The questionnaire was originally formed for a sample of teachers, but it was adapted for students with minimal modifications. The statements form three latent factors. The Value factor consists of fourteen manifest statements, referring to intrinsic and individual values of subjects in implementing teaching activities with the help of digital media (e.g., "The use of computer technology in the teaching promotes the development of students' interpersonal skills, e.g., ability to relate or work with others"). The Expectancy factor consists of nine manifest statements, referring to students' assessment of expected success in learning by using digital media (e.g., "The use of computer technology in teaching is effective because I believe I can implement it successfully."). The Cost factor consists of nine manifest statements oriented towards student's effort invested to perform some task by using digital media (e.g., "The use of computer technology in teaching is too costly in terms of resources, time and effort."). Exploratory factor analysis (PCA) with oblimin rotation, saturation higher than .40 , and eigenvalue greater than 1 (PCA) $(\mathrm{KMO}=.899$; Bartlett's test of sphericity was significant, $\chi 2=3901.309 ; \mathrm{p}=.000$ ) yielded three factors which collectively accounted for $63.53 \%$ of the total variance. The three obtained factors almost completely replicated the original factor structure. The first factor had loadings on thirteen statements of the Value factor (the eigenvalue was 5.34, and it explained $30.54 \%$ of the variance). The second factor had loadings on seven statements of the Cost factor (the eigenvalue was 3.77, and it explained $18.52 \%$ of the variance). The third factor had loadings on eleven statements of the Expectancy factor (the eigenvalue 
was 1.87 , and it explained $15.47 \%$ of the variance). Four statements did not have significant loadings. The factors obtained in this way almost completely replicated the original factor structure, thus, it was justified to use this questionnaire in its original form, which was also confirmed by satisfactory reliability of the composite factors (Table 1).

The data on classroom quality were collected by the Student perception of classroom quality - SPOCQ (Gentry \& Owen, 2004) questionnaire, which consists of thirtyfour manifest statements on a 5-point Likert scale ( $1=$ Strongly disagree, $2=$ Disagree, 3 = Undecided, 4 = Agree, 5 = Strongly agree). Manifest statements form five factors of classroom quality. The Appeal factor consists of seven statements, and it refers to students' satisfaction with teaching activities (e.g., "I look forward to learning new things in this class."). The Challenge factor consists of seven statements and refers to students' opinions about how challenging the teaching activities are (e.g., "I find my class assignments a good challenge."). Furthermore, the Choice factor consists of seven statements and it is aimed at the perception about the possibility of choosing how things are done and what activities are selected (e.g." "I am given lots of choices in my class."). The Meaningfulness factor consists of five statements and it refers to students' perception of meaningfulness that teaching activities and contents learned have for real life (e.g., "The teacher applies the lessons to practical experiences."). The Academic self-efficacy factor consists of eight statements and it refers to students' assessment about the level of the learning outcomes achieved (e.g., "I can easily understand reading assignments for this class."). The questionnaire was used with the authors' permission and was translated from English to Croatian using the back translation procedure. Exploratory factor analysis (PCA) with oblimin rotation, saturation higher than .40, and eigenvalue greater than 1 (PCA) (KMO = .934; Bartlett's test of sphericity was significant, $\chi 2=7990.768 ; \mathrm{p}=.00$ ) yielded five factors which collectively accounted for $61.15 \%$ of the total variance. The three obtained factors almost completely replicated the original factor structure. The first factor had loadings on six statements (the eigenvalue was 12.27 , and it explained $30.08 \%$ of the variance), five of which belonged to the Meaningfulness factor. The second factor had loadings on seven statements (the eigenvalue was 2.65 , and it explained $8.8 \%$ of the variance), all of which belonged to the Academic self-efficacy factor. The third factor had loadings on eight statements (the eigenvalue was 2.09 , and it explained $7.14 \%$ of the variance), seven of which belonged to the Appeal factor. The fourth factor had loadings on six statements (the eigenvalue was 1.55 , and it explained $5.77 \%$ of the variance), all of which belonged to the Challenge factor. The fifth factor had loadings on six statements (the eigenvalue was 1.15 , and it explained $4.76 \%$ of the variance), all of which belonged to the Choice factor. Three statements did not have loadings higher than .40 . Obtained in this way, they almost completely replicated the original structure of the questionnaire. Thus, it was justified to use it in its original form, which was also confirmed by satisfactory reliability of composite factors (Table 1). 
Jurčev, Topolovčan and Maras: The Role of Goal Orientations and the Use of Digital Media ...

Table 1

Descriptive characteristics of subscales

\begin{tabular}{lccccc}
\hline \multicolumn{1}{c}{ Factors } & $M$ & SD & Min & Max & a \\
\hline SPOCQ - Appeal & 3.00 & .89 & 1 & 5 & .88 \\
SPOCQ - Challenge & 3.11 & .80 & 1 & 5 & .82 \\
SPOQ - Choice & 3.40 & .82 & 1 & 5 & .80 \\
SPOQ - Meaningfulness & 3.38 & 1.00 & 1 & 5 & .90 \\
SPOQ - Academic self-efficacy & 3.44 & .82 & 1 & 5 & .86 \\
COU - Learning & 3.73 & .99 & 1 & 5 & .89 \\
COU - Performance & 3.57 & .91 & 1 & 5 & .77 \\
COU - Avoidance & 3.59 & .87 & 1 & 5 & .77 \\
TIQ - Value & 3.57 & .62 & 1 & 5 & .83 \\
TIQ - Expectancy & 3.62 & .58 & 1 & 5 & .72 \\
TIQ - Cost & 3.57 & .59 & 1 & 5 & .73 \\
\hline
\end{tabular}

The data were collected in March 2017 (as part of a more extensive study), by penand-paper method. The study was conducted in line with the ethical codes of conduct involving child and youth participation in research, i.e., completely anonymously and voluntarily, and students were free to withdraw from the research at any time while filling out the questionnaire.

\section{Results}

Descriptive analysis showed (Table 1) that students were not certain about their classroom quality, i.e., their assessment was neutral. Furthermore, their orientation towards learning, performance, and avoidance was mildly above average. Their assessment of the value of digital media in learning, expectations about its use, as well as benefits from putting in effort in its implementation, was also positive and mildly above average.

Hierarchical regression analysis was used to examine predictor contribution of demographic characteristics of students, their goal orientations, the level of digital media equipment in schools and (reasons for) their use in explaining certain aspects of classroom quality. Such order of predictors is explained by demographic characteristics being mostly invariable and goal orientations coming before the level of equipment. It means that they are constant regardless of the school's technological equipment or lack thereof. The use of digital media comes last (correlation matrix, Appendix 1).

In hierarchical regression analysis (Table 2), demographic characteristics, goal orientations, the level of digital media equipment in schools, and the use of digital media in teaching as predictors accounted for $30.6 \%$ of the variance of appeal of teaching activities, with goal orientations explaining $24.8 \%$, and other predictors explaining $15.2 \%$ (the level of digital media equipment in schools $3.7 \%$, demographic characteristics $1.2 \%$, and the use of digital media $0.7 \%$ ). Predictors explained $26.1 \%$ of the variance of challenge of teaching activities as a classroom quality dimension. Goal orientations in learning explained the largest amount of variance (20\%), whereas other predictors explained additional 6.1\% (the level of digital media equipment 
in schools $3.1 \%$, the use of media $2.1 \%$, and demographic characteristics $0.8 \%$ ). The predictor set accounted for $27.8 \%$ of the choice of work activities and teaching activities. Goal orientations explained $22 \%$, whereas other variables (the level of digital media equipment in schools $3.4 \%$, the use of digital media $2.2 \%$, and demographic characteristics $0.2 \%$ ) explained additional $5.8 \%$.

Table 2

Demographic characteristics of students, goal orientations, the level of digital media equipment in schools, and their use as predictors of classroom quality dimensions

\begin{tabular}{|c|c|c|c|c|c|}
\hline \multirow{2}{*}{$\begin{array}{c}\text { Predictors } \\
\beta\end{array}$} & Appeal & Challenge & Choice & Meaningfulness & Self-efficacy \\
\hline & $\beta$ & $\beta$ & $\beta$ & $\beta$ & \\
\hline $\begin{array}{l}\text { 1: demographic } \\
\text { characteristics }\end{array}$ & $\begin{array}{c}\Delta R^{2}=.012 \\
p=.265\end{array}$ & $\begin{array}{c}\Delta R^{2}=.008 \\
p=.456\end{array}$ & $\begin{array}{c}\Delta R^{2}=.002 \\
p=.942\end{array}$ & $\begin{array}{c}\Delta R^{2}=.009 \\
p=.420\end{array}$ & $\begin{array}{c}\Delta R^{2}=.112 \\
p=000\end{array}$ \\
\hline Gender & .07 & .03 & .01 & .03 & .02 \\
\hline School & -.07 & .02 & -.01 & -.04 & .03 \\
\hline Grade & -.04 & .04 & .03 & -.02 & .33 \\
\hline Class & -.01 & .07 & -.01 & -.07 & .03 \\
\hline $\begin{array}{l}\text { 2: goal } \\
\text { orientations }\end{array}$ & $\begin{array}{c}\Delta R^{2}=24.8 \\
p=.000\end{array}$ & $\begin{array}{c}\Delta R^{2}=.200 \\
p=.000\end{array}$ & $\begin{array}{c}\Delta R^{2}=.220 \\
p=.000\end{array}$ & $\begin{array}{c}\Delta R^{2}=.127 \\
p=.000\end{array}$ & $\begin{array}{c}\Delta R^{2}=.148 \\
p=.000\end{array}$ \\
\hline Gender & -.01 & -.02 & -.05 & -.01 & -.03 \\
\hline School & -.04 & .06 & .02 & -.01 & .06 \\
\hline Grade & -.07 & .01 & .00 & -.04 & $.30^{* *}$ \\
\hline Class & -.01 & .06 & -.02 & -.08 & .03 \\
\hline Learning & $.497^{* *}$ & $.41^{* *}$ & $.43^{* *}$ & $.362^{* *}$ & $.33^{* *}$ \\
\hline Performance & .01 & .08 & $.12^{*}$ & .00 & $.11^{*}$ \\
\hline Avoidance & -.085 & .01 & $.11^{*}$ & .00 & $.10^{*}$ \\
\hline $\begin{array}{l}\text { 3: the level of } \\
\text { digital media } \\
\text { equipment in } \\
\text { schools }\end{array}$ & $\begin{array}{c}\Delta R^{2}=.037 \\
p=.003\end{array}$ & $\begin{array}{c}\Delta R^{2}=.031 \\
p=.019\end{array}$ & $\begin{array}{c}\Delta R^{2}=.034 \\
p=.009\end{array}$ & $\begin{array}{c}\Delta R^{2}=.037 \\
p=.011\end{array}$ & $\begin{array}{c}\Delta R^{2}=.012 \\
p=.439\end{array}$ \\
\hline Gender & -.01 & -.02 & -.05 & -.00 & -.04 \\
\hline School & -.02 & .08 & .03 & -.00 & .07 \\
\hline Grade & -.04 & .02 & .01 & -.04 & $.30^{* *}$ \\
\hline Class & -.01 & .07 & -.01 & -.06 & .03 \\
\hline Learning & $.490^{* *}$ & $.41^{* *}$ & $.40^{* *}$ & $.335^{* *}$ & $.32^{* *}$ \\
\hline Performance & .01 & .07 & $.11^{*}$ & .01 & $.11^{*}$ \\
\hline Avoidance & -.06 & .03 & .03 & .02 & .00 \\
\hline Computer & .01 & -.03 & .04 & -.05 & .01 \\
\hline Internet & -.04 & -.04 & -.07 & -.05 & .05 \\
\hline $\begin{array}{l}\text { Computer } \\
\text { prog. }\end{array}$ & .05 & .05 & .10 & $.13^{*}$ & -.01 \\
\hline Projectors & -.02 & -.01 & .01 & -.04 & .01 \\
\hline $\begin{array}{l}\text { Smart } \\
\text { boards }\end{array}$ & $-.11^{*}$ & $-.13^{*}$ & $-.11^{*}$ & -.06 & $-.11^{*}$ \\
\hline Tablet & $.137^{* *}$ & $.101 *$ & .06 & -.06 & .05 \\
\hline Social media & $.09^{*}$ & .09 & .09 & $.15^{* *}$ & .01 \\
\hline
\end{tabular}


Jurčev, Topolovčan and Maras: The Role of Goal Orientations and the Use of Digital Media ...

\begin{tabular}{lccccc}
\hline \multirow{2}{*}{$\begin{array}{c}\text { Predictors } \\
\beta\end{array}$} & Appeal & Challenge & Choice & Meaningfulness & Self-efficacy \\
\cline { 2 - 6 } 4: use of digital & $\beta$ & $\beta$ & $\beta$ & $\beta$ & \\
media & $\Delta R^{2}=.007$ & $\Delta R^{2}=.021$ & $\Delta R^{2}=.022$ & $\Delta R^{2}=.020$ & $\Delta R^{2}=.016$ \\
Gender & $p=.254$ & $p=.009$ & $p=.006$ & $p=.017$ & $p=.027$ \\
School & -.01 & -.02 & -.04 & .01 & -.03 \\
Grade & -.02 & .07 & .03 & -.01 & .06 \\
Class & -.05 & .01 & .01 & -.05 & $.29^{* *}$ \\
Learning & -.01 & .07 & .01 & -.05 & .04 \\
Performance & $.479^{* *}$ & $.38^{* *}$ & $.385^{* *}$ & $.323^{* *}$ & $.31^{* *}$ \\
Avoidance & -.01 & .05 & .07 & -.00 & .09 \\
Computer & .01 & .01 & .00 & -.01 & -.01 \\
Internet & -.04 & -.02 & .05 & -.04 & .01 \\
Computer & .046 & -.04 & -.07 & -.05 & .05 \\
prog. & & .04 & .09 & $.12^{*}$ & -.02 \\
Projectors & -.02 & -.02 & .01 & -.04 & .02 \\
Smart & $-.11^{*}$ & $-.13^{*}$ & $-.11^{*}$ & -.06 & $-.11^{*}$ \\
boards & $.13^{* *}$ & .09 & .05 & -.07 & .05 \\
Tablet & $.11^{*}$ & $.09^{*}$ & $.09^{*}$ & $.158^{* *}$ & .02 \\
Social media & .02 & $.11^{*}$ & .06 & .01 & -.09 \\
Value & .02 & $.10^{*}$ & .03 & .01 & .08 \\
Expectancy & .03 & -.02 & .08 & $.13^{*}$ & $.12^{*}$ \\
Cost & .04 & $R^{2}=.261$ & $R^{2}=.278$ & $R^{2}=.193$ & $R^{2}=.289$ \\
& $R^{2}=.306$ & $F=8.371$ & $F=5.819$ & $F=9.880$ \\
& $F=10.67$ & $F=8.59$ & $F=900$ & $p=.000$ \\
\hline & $p=.000$ & $p=.000$ & $p=.000$ & $p=.000$ &
\end{tabular}

Note. ${ }^{*} p<.05 ;{ }^{* *} p<.01$

Furthermore, the predictor set accounted for $19.3 \%$ of variance of meaningfulness that class content has for students. Goal orientations explained 12.7\%, whereas other variables (the level of digital media equipment in schools $3.7 \%$, the use of digital media $2 \%$, and demographic characteristics $0.9 \%$ ) explained additional $6.3 \%$. Predictors explained $28.9 \%$ of variance of academic self-efficacy, with goal orientation explaining $14.8 \%$ of the variance, whereas other variables (the use of digital media $1.6 \%$, the level of digital media equipment in schools $1.2 \%$, and demographic characteristics $11.2 \%$ ) explained additional $5.1 \%$.

\section{Discussion}

Positive perception of digital media implementation in teaching can be interpreted by the fact that the students belong to the Net Generation; they were born and raised in a digital media environment. On the other hand, they did not experience teaching as they would have wanted it to be, i.e., it did not satisfy their need for school learning. Furthermore, despite the students' learning orientation, they were also performance and avoidance-oriented, which may be caused by their aspiration for higher grades.

Regarding the appeal of teaching activities, the goal orientations (primarily learning orientation) explained most of the variance. From the results, it is evident that students 
accept learning as a goal, which encourages them to explore, initiate and solve tasks, and the effort they invest ultimately results in activating abilities and achieving pride and satisfaction (Dweck, 1986). In all steps of regression analysis, gender was not a significant predictor, which is contrary to some previous studies, in which girls had higher motivation for learning (e.g., McKenna, Kear, \& Ellsworth, 1995), but also tend to be more learning-oriented (Patrick, Ryan, \& Pintrich, 1999). In accordance with the theories on implementation of digital media in teaching (Dillon \& Gabbard, 1998; Rodek, 2011; Tamim et al., 2011), and contrary to the expectations of current educational policies in the Republic of Croatia, the level of digital media equipment in schools and the use of digital media in teaching as predictors explained an extremely small portion of variance of the appeal of teaching activities. However, in the final step of the analysis, if a school was less equipped with smart boards, but betterequipped with social media and tablets, these were individually significant predictors of the challenging environment of the classroom. This can be substantiated by the fact that digital media are a powerful and flexible learning tool (Bereiter, 2002) but their integration can be problematic (Russell, 1999). Research results reveal existing problems, which are the reason for students not giving high assessments regarding media implementation and use when it comes to classroom quality. Implementation of digital media and their use requires systematic planning through curriculum, educating teachers on their use, and systematic support for teachers (Gilmore, 1995). Otherwise, according to research results, it will be only a modest, peripheral modification in teaching and learning, which means new technologies will merely continue old practices (Cuban, Kirkpatrick, \& Peck, 2001).

The largest portion of the variance of the challenge dimension was explained by goal orientations, with emphasis on learning orientation (intrinsic motivation). A possible reason for this is the fact that challenging activities are associated with positive affective perception, which motivates students to actively engage in a task (Pintrich \& Schrauben, 1992). It requires additional engagement of the teacher in terms of motivating the students. Teachers strive to teaching challenges in order to ensure students' motivation for learning, otherwise students who do not feel challenged in the educational process feel bored and frustrated for not using their full potential (Archambault, Westberg, Brown et al., 1993). The level of digital media equipment in schools and its use explained a minor portion of variance of challenge, although, in the final step of the analysis, if a school was less equipped with smart boards, but betterequipped with tablets and computers, and there was a higher value and expectancy regarding the use of media, these were individually significant predictors of appeal of teaching activities. Learning is meaningful when it is optimal, the subjects are relevant, connected to real life, interesting and stimulating for students' imagination (Phenix, 1964). That is why it was expected that goal orientations, with emphasis on learning orientation, would explain the largest portion of the total variance of meaningfulness. Students who do not see the meaning of the contents learned lose will and motivation, 
which is congruent with some previous studies that show a decline in motivation for learning (e.g., Anderman \& Midgley, 1997). As in other dimensions, equipment, its use, and motivation for using media explained a minor percentage of variance of meaningfulness, with schools better equipped with computer programs and higher assessment of benefits relating to effort invested in using media being significant individual predictors. Furthermore, the choice of work activity in teaching was mostly explained by goal orientations, with emphasis on learning orientation. A possible reason for this could be that a well-organised class gives students a choice and allows them a certain level of autonomy (Deci, 1995), which increases students' motivation (Eccles \& Midgley, 1989) and leads them to internalization of goal orientation. It is evident here also that a minor portion of variance of the classroom quality dimension was explained by the use and motivation to use digital media, with predictors of choice being individually more significant if the school was less equipped with smart boards and better equipped with social media. After satisfying the abovementioned dimensions of classroom quality (challenge, choice, meaningfulness), a mechanism for building greater academic self-efficacy is formed (Chae \& Gentry, 2011), which is why goal orientations (learning orientation for the most part) as predictors explain the largest portion of variance of academic self-efficacy. The results of the final step of regression analysis clearly showed that, as could have been expected, students with better grades had better developed academic self-efficacy. On the other hand, even though the level of media equipment in schools and its use explained a small portion of variance of self-efficacy, it is evident that in the final step of the analysis, a school less equipped with smart boards and expected benefit from the effort put in the use of media were significant predictors. It is evident that goal orientations explained a high percentage of classroom quality, i.e., its separate dimensions. Even though students differ in terms of their goal orientation, classroom quality (e.g., Butler, 2006; Meece \& Miller, 1999) should be a powerful resource for activating students' abilities.

\section{Conclusion}

Based on this research, several conclusions could be formed. Namely, students were indifferent towards classroom quality, i.e., they considered it to be moderate regarding the dimensions examined. On the other hand, regarding goal orientations, students were mildly above average oriented towards learning and performance, but also avoidance. Moreover, students' assessment of digital media implementation, both in terms of value and expectancy, was mildly positive, thus, they were willing to put in extra effort when it comes to their use in the classroom. It is clear that demographic characteristics, such as gender, class, grade, etc., are becoming less significant as factors of teaching, and therefore less significant predictors of its quality. However, goal orientations are the most significant element in explaining the total prediction of classroom quality, with learning orientation being the most significant predictor of positive perception of classroom quality. In this respect, students want 
to learn, participate, explore, present, get good grades, but, in addition to optimal working conditions, they should be provided with a challenging and stimulating learning environment to become more engaged. By improving classroom quality, students' interest, as well as motivation, increase, i.e., the forming of performance and avoidance orientation can be neutralized. The level of digital media equipment in schools and use of media in classroom teaching are not underlined as an important segment of prediction of classroom quality perception. Digital media can be useful, but their implementation and use require teachers to have the ability to create adequate didactic-teaching methodology arrangements which are student-oriented, and which would then be recognized by students as indispensable predictors of classroom quality. In this respect, it is clear that digital media in education (the level of digital media equipment in schools and their use in the classroom) are not significant predictors of (a more positive students' perception of) classroom quality. On the contrary, students' intrinsic learning conditions are significant in terms of motivation for learning manifested in goal orientations, primarily learning orientation. Finally, some limitations of the research should be mentioned. Firstly, in addition to the investigated factors, additional factors which could be predictors of classroom quality should be included. On the other hand, dimensions of classroom quality should be investigated as predictors of development of certain students' characteristics. Moreover, more complete results would be obtained if research was conducted on larger samples, i.e., samples of primary education students, upper secondary education students, but also teachers and parents. The limitations mentioned are also possibilities, challenges and recommendations for future research of this problem.

\section{References}

Anderman, E. M., \& Midgley, C. (1997). Changes in achievement goal orientations, perceived academic competence, and grades across the transition to middle-level schools. Contemporary Educational Psychology, 22, 269-298. https://doi.org/10.1006/ceps.1996.0926

Archambault, F. X., Jr., Westberg, K. L., Brown, S. W., Hallmark, B. W., Zhang, W., \& Emmons, C. L. (1993). Classroom practices used with gifted third and fourth grade students. Journal for the Education of the Gifted, 16(2), 103-119. https://doi.org/10.1177/016235329301600203

Bereiter, C. (2002). Education and mind in the knowledge age. Mahwah, NJ: Lawrence Erlbaum.

Butler, R. (2006). Are mastery and ability goals both adaptive? Evaluation, initial goal construction and the quality of task engagement. British Journal of Educational Psychology, 76, 595-611. https://doi.org/10.1348/000709905X52319

Chae, Y., \& Gentry, M. (2007). Korean high school student perception of classroom quality: Validation research. Gifted and Talented International, 22(1), 68-76. https://doi.org/10.10 $\underline{80 / 15332276.2007 .11673497}$

Chae, Y., \& Gentry, M. (2011). Gifted and general high school students' perception of learning and motivational constructs in Korea and United States. High Ability Studies, 22(1), 103118. https://doi.org/10.1080/13598139.2011.577275 
Coley, R. J., Cradler, J., \& Engel, P. K. (1997). Computers and classrooms: The status of technology in U.S. schools. Princeton, NJ: Policy Information Center, Educational Testing Service.

Cuban, L., Kirkpatrick, H., \& Peck, C. (2001). High access and low use of technologies in high school classrooms: explaining an apparent paradox. American Educational Research Journal, 38(4), 813-834. https://doi.org/10.3102/00028312038004813

Deci, E. L. (1995). Why we do what we do: The dynamics of personal autonomy. New York: Putnam's Sons.

Dillon, A., \& Gabbard, R. (1998). Hypermedia as an educational technology. A review of the quantitative research literature on learner comprehension, control and style. Review of Educational Research, 68, 322-349. https://doi.org/10.3102/00346543068003322

Dweck, C. S. (1986). Motivational processes affecting learning. American Psychologist, 41, 1040-1048. https://doi.org/10.1037/0003-066X.41.10.1040

Eccles, J. S. (2005). Subjective task value and the Eccles et al. model of achievement-related choices. In A. J. Elliot, \& C. S. Dweck (Eds.), Handbook of competence and motivation (pp. 105-121). New York London: Guilford Press.

Eccles, J. S., \& Midgley, C. (1989). Stage environment fit: Developmentally appropriate classrooms for young adolescents. In C. Ames, \& R. Ames (Eds.), Research on motivation in education, Goals and cognitions (pp. 139-186). New York: Academic Press.

Eccles, J. S., \& Wigfield, A. (1995). In the mind of the actor: The structure of Adolescents' achievement task values and expectancy-related beliefs. Personality and social psychology bulletin, 21(3), 215-225. https://doi.org/10.1177/0146167295213003

Eccles J. S., Adler, T. F., Futterman, R., Goff, S. B., Kaczala, C. M., Meece, J. L., \& Midgley, C. (1983). Expectancies, values, and academic behaviors. In J. T. Spence (Ed.), Achievement and achievement motivation (pp. 75-146). San Francisco, CA: W. H. Freeman.

Gentry, M., \& Gable, R. K. (2001). My class activities: A survey instrument to assess students perceptions of interest, challenge, choice and enjoyment in their classrooms. Mansfield Center, CT: Creative Learning Press. https://doi.org/10.1037/t01972-000

Gentry, M., \& Owen, S. V. (2004). Secondary student perceptions of classroom quality. The Journal of Secondary Gifted Education, 16(1), 20-29. https://doi.org/10.4219/jsge-2004-464

Gentry, M., Gable, R. K., \& Rizza, M. G. (2002). Students' Perception of Classroom Activities: Are There Grade-Level and Gender Differences? Journal of Educational Psychology, 94(3), 539-544. https://doi.org/10.1037//0022-0663.94.3.539

Gilmore, A. M. (1995). Turning teachers on to computers: Evaluation of a teacher development program. Journal of Research on Computing in Education, 27(3), 251-269. https://doi.org/10.1080/08886504.1995.10782131

Hattie, J. (2009). Visible learning: A synthesis of over 800 meta-analyses relating to achievement. London and New York: Routledge. https://doi.org/10.4324/9780203887332

Matijević, M., Drljača, M., \& Topolovčan, T. (2016). Učeničke procjene vlastitih aktivnosti $\mathrm{u}$ nastavi likovne kulture [Self-assessment of student activities in art education]. Učenje i nastava, 2(1), 129-150.

Matijević, M., Opić, S., \& Rajić, V. (2015). Student's views of classroom activities in secondary education in Croatia. Didactica Slovenica, 30(3-4), 36-49. 
Matijević, M., Topolovčan, T., \& Rajić, V. (2017). Nastavničke procjene upotrebe digitalnih medija i konstruktivističke nastave $u$ primarnom i sekundarnom obrazovanju [Teacher assessment related to the use of digital media and constructivist learning in primary and secondary education]. Croatian Journal of Education, 19(2), 563-603. https://doi. org/10.15516/cje.v19i2.2411

McKenna, M. C., Kear, J. D., \& Ellsworth, A. R. (1995). Children's Attitudes toward Reading: A National Survey. Reading Research Quarterly, 30(4), 934-956. https://doi. org/10.2307/748205

Meece, J. L., \& Miller, S. D (1999). Changes in elementary school children's achievement goal for reading and writing: results of a longitudinal and an intervention study. Scientific Studies of Reading, 3, 207-229. https://doi.org/10.1207/s1532799xssr0303 2

Niemivitra, M. (1996). Motivational-cognitive components in self-regulated learning. Paper presented at the 5th International Conference on Motivation. Landau, Germany.

Niemivirta, M. (1998). Individual differences in motivational and cognitive factors affecting self-regulated learning: A pattern-oriented approach. In P. Nenniger, R. S. Jager, A. Frey A., \& M. Wosnitza (Eds.), Advances in Motivation (pp. 23-42). Landau: Verlag Empirische Padagogik.

Niemivirta, M. (2002). Individual differences and developmental trends in motivation: integrating person-centred and variable-centred methods. In P. R. Pintrich, \& M. L. Maehr (Eds.), Advances in Motivation and achievement (pp. 241-275). Amsterdam: JAI Press.

Patrick, H., Ryan, A. M., \& Pintrich, P. R. (1999). The differential impact of extrinsic and mastery goal orientations on males' and females' self-regulated learning. Learning and Individual Differences, 11(2), 153-171. https://doi.org/10.1016/S1041-6080(00)80003-5

Phenix, P. H. (1964). Realms of Meaning, A Philosophy of the Curriculum for General Education. New York: McGraw-Hill Book Company.

Pintrich, P. R., \& Schrauben, B. (1992). Students' motivational beliefs and their cognitive engagement in classroom academic tasks. In D. Schunk, \& J. Meece (Eds.), Student perceptions in the classroom (pp. 149-183). Hillsdale, NJ: Lawrence Erlbaum Associates.

Rijavec, M., \& Brdar, I. (2002). Coping with school failure and self-regulated learning. European Journal of Psychology of Education, 17(2), 177-194. https://doi.org/10.1007/ $\underline{\mathrm{BF} 03173257}$

Rodek, S. (2011). Novi mediji i nova kultura učenja [New media and new learning culture]. Napredak, 152(1), 9-28.

Roeser, R. W., Strobel, K. R., \& Quihuis, G. (2002). Studying early adolescents' academic motivation, social-emotional functioning, and engagement in learning: variableand person-centred approaches. Anxiety, Stress \& Coping, 15, 345-368. https://doi. org/10.1080/1061580021000056519

Russell, T. L. (1999). The no significant difference phenomenon. Raleigh, NC: North Carolina State University Press.

Stanišak Pilatuš, I., Jurčec, L., \& Rijavec, M. (2013). Ciljne orijentacije u učenju: dobne i spolne razlike i povezanost sa školskim uspjehom [Goal orientations: age and gender differences and correlation to academic achievement]. Napredak, 154(3), 473-491.

Tamim, R. M., Bernard, R. M., Borokhovski, E., Abrami, P. C., \& Schmid, R. F. (2011). What forty years of research says about the impact of technology on learning: A second-order 
meta-analysis and validation study. Review of Educational Research, 81(1), 4-28. https:// doi.org/10.3102/0034654310393361

Timmerman, C. E., \& Kruepke, K. A. (2006). Computer-assisted instruction, media richness, and college student performance. Communication Education, 55(1), 73-104. https://doi. org/10.1080/03634520500489666

Topolovčan, T., \& Matijević, M. (2016). Characteristics of using digital media as predictors of constructivist teaching in lower secondary education in Croatia. International Journal of Knowledge, Innovation and Entrepreneurship, 4(1-3), 35-52.

Topolovčan, T., Rajić, V., \& Matijević, M. (2017). Konstruktivistička nastava: teorija i empirijska istraživanja [Constructivist teaching: theory and empirical research]. Zagreb: Učiteljski fakultet Sveučilišta u Zagrebu.

Tuominen-Soini, H., Salmela-Aro, K., \& Niemivirta, M. (2008). Achievement goal orientations and subjective well-being: A person-centred analysis. Learning and Instruction, 18, 251266. https://doi.org/10.1016/j.learninstruc.2007.05.003

Wigfield, A., \& Eccles, J. S. (2000). Expectancy-value theory of achievement motivation. Contemporary Educational Psychology, 25, 68-81. https://doi.org/10.1006/ceps.1999.1015

Wozney, L., Venkatesh, V., \& Abrami, P. C. (2006). Implementing computer technologies: Teacher's perceptions and practice. Journal of Technology and Teacher Education, 14(1), 173-207.

\section{Antonio Jurčev}

A. G. Matoš Elementary school

Aleja Antuna Augustinčića 12, 10000 Zagreb, Croatia

lidrano@osagm.hr

\section{Tomislav Topolovčan}

University of Zagreb, Faculty of Teacher Education

Savska cesta 77, 10000 Zagreb, Croatia

tomislav.topolvcan@ufzg.hr

\section{Nevenka Maras}

University of Zagreb, Faculty of Teacher Education

Savska cesta 77, 10000 Zagreb, Croatia

nevenka.maras@ufzg.hr 


\section{Appendix}

\section{Correlation matrix of (Pearson) correlations between all variables}

\begin{tabular}{|c|c|c|c|c|c|c|c|c|c|c|c|c|c|c|c|c|c|c|c|c|c|}
\hline Factors & 2. & 3. & 4. & 5. & 6. & 7. & 8. & 9. & 10. & 11. & 12. & 13. & 14. & 15. & 16. & 17. & 18. & 19. & 20. & 21. & 22. \\
\hline 1. gender & .02 & $.13^{*}$ & $-.11^{*}$ & $.11^{*}$ & .06 & -.13 & -.06 & .05 & -.01 & -.02 & -.05 & .05 & .01 & -.04 & .01 & $-.12^{*}$ & * $.11^{*}$ & .02 & .01 & .03 & .05 \\
\hline 2. school & 1.00 & $-.10^{*}$ & .06 & -.04 & -.03 & -.04 & $.10^{*}$ & $.12^{*}$ & .09 & .05 & $.14^{* *}$ & -.03 & .04 & -.06 & .06 & -.05 & $-.11^{*}$ & .05 & -.03 & -.04 & $\begin{array}{ll}4 & -.03\end{array}$ \\
\hline 3. grade & & 1.00 & .01 & .07 & $.14^{* *}$ & .01 & -.05 & $-.14^{* *}$ & -.09 & -.07 & $-.14^{* *}$ & * $-.14^{* *}$ & * $-.14^{* *}$ & $* .02$ & $.10^{*}$ & .06 & -.03 & .06 & $.09^{*}$ & $-.10^{*}$ & $* .36^{* *}$ \\
\hline 4. class & & & 1.00 & .02 & -.05 & .06 & .021 & -.03 & $-.11^{*}$ & -.02 & .03 & -.01 & -.01 & -.07 & -.03 & $-.14^{* *}$ & $*-.02$ & .07 & -.01 & $-.09 *$ & $* \quad .02$ \\
\hline 5. learning & & & & 1.00 & $.38^{* *}$ & -.01 & $.10^{*}$ & $.10^{*}$ & $.16^{* *}$ & $.16^{* *}$ & $-.12^{*}$ & $-.15^{* *}$ & * $.14^{* *}$ & $.18^{* *}$ & ${ }^{*} .24^{* *}$ & * $.11 *$ & $.47^{* *}$ & $.43^{* *}$ & $* .43^{* *}$ & * $.36^{* *}$ & **. $.37^{* *}$ \\
\hline 6. performance & & & & & 1.00 & $.25^{* *}$ & -.03 & -.03 & $-.11^{*}$ & -.01 & $-.09 *$ & .02 & $-.10^{*}$ & $.12^{*}$ & $.31 * *$ & * $.11^{* *}$ & * $.09 *$ & $.23 * *$ & * $.12^{*}$ & $.13^{* *}$ & $* .26 * *$ \\
\hline 7. avoidance & & & & & & 1.00 & .04 & -.04 & .02 & $.13^{* *}$ & .03 & $-.12^{*}$ & $-.13^{* *}$ & $.17^{*}$ & $.10^{*}$ & $.11^{*}$ & $-.11^{*}$ & $.15^{* *}$ & $.10^{*}$ & $.11 *$ & * .02 \\
\hline 8. computer & & & & & & & 1.00 & $.28^{* *}$ & $.48^{* * *}$ & $.34^{* *}$ & $.27^{* *}$ & $.09 *$ & $.24^{* *}$ & .01 & $-.23^{* *}$ & $*-.02$ & $.10^{*}$ & $.11^{*}$ & $.13^{* *}$ & $* .23 * *$ & $* .21 * *$ \\
\hline 9. internet & & & & & & & & 1.00 & $.30^{* *}$ & $.29 *$ & $.24 *$ & $.10^{*}$ & $.25 * *$ & $.10^{*}$ & $.10^{*}$ & $-.12 *$ & $* .12^{*}$ & $-.11^{*}$ & $-.09 *$ & * -.01 & $-.10^{*}$ \\
\hline 10. programs & & & & & & & & & 1.00 & $.36 *$ & $.32 * *$ & $.19 * *$ & $.29 * *$ & $.09^{*}$ & $.012^{*}$ & $* .21^{* *}$ & $* .15 * *$ & $.10^{*}$ & $.20 *$ & $* .15^{* *}$ & $* .02$ \\
\hline 11. projector & & & & & & & & & & 1.00 & $.36 * *$ & $.34^{* *}$ & $.11 *$ & $.19^{* *}$ & -.02 & $.17^{* *}$ & $* .01$ & $-.11^{*}$ & $.15 * *$ & $*-.10 *$ & * -.01 \\
\hline 12. boards & & & & & & & & & & & 1.00 & $.31^{* *}$ & $.21 * *$ & $.12^{*}$ & -.00 & .00 & $-.10^{*}$ & $-.14^{* *}$ & * -.05 & $-.10^{*}$ & ${ }^{*}-.16^{* *}$ \\
\hline 13. tablet & & & & & & & & & & & & 1.00 & $.27 * *$ & $.12^{*}$ & $-.10^{*}$ & $* .12^{*}$ & $.12^{*}$ & $.10^{*}$ & $.14^{* *}$ & * -.03 & $-.11^{*}$ \\
\hline 14. media & & & & & & & & & & & & & 1.00 & -.06 & $-.17^{* *}$ & $*-.11^{*}$ & $* .13 * *$ & $.11^{*}$ & $.11^{*}$ & $.13^{* *}$ & $* \quad-.03$ \\
\hline 15. value & & & & & & & & & & & & & & 1.00 & $.54 *$ & $* .66^{* *}$ & $* .12^{*}$ & $.24^{* *}$ & $* 27 * *$ & $* .17^{* *}$ & $* .12^{*}$ \\
\hline 16. expectancy & & & & & & & & & & & & & & & 1.00 & $.53^{* *}$ & ${ }^{*} .13^{* *}$ & $.28^{* *}$ & $.25^{* *}$ & * $.15^{* *}$ & $* .21 * *$ \\
\hline 17. cost & & & & & & & & & & & & & & & & 1.00 & $.17^{* *}$ & $.13^{* *}$ & $.22 *$ & * $.18^{* *}$ & $.15^{* *}$ \\
\hline 18. appeal & & & & & & & & & & & & & & & & & 1.00 & $.58^{* *}$ & $* .58 *$ & * $.55^{* *}$ & $* .45^{* *}$ \\
\hline 19. challenge & & & & & & & & & & & & & & & & & & 1.00 & $.52 * *$ & $* .45^{* *}$ & $* .46^{* *}$ \\
\hline 20. choice & & & & & & & & & & & & & & & & & & & 1.00 & $.65^{* *}$ & $* .54 * *$ \\
\hline 21. meaning & & & & & & & & & & & & & & & & & & & & 1.00 & $.48^{* *}$ \\
\hline 22. self-efficacy & & & & & & & & & & & & & & & & & & & & & 1.00 \\
\hline
\end{tabular}

Note. ${ }^{*} p<.05 ;{ }^{* *} p<.01$ 


\section{Uloga ciljnih orijentacija u učenju i upotrebi digitalnih medija $u$ kvaliteti nastave završnih razreda osnovnog obrazovanja}

\section{Sažetak}

Cilj istraživanja bio je ispitati obilježja i prediktorsku ulogu ciljnih orijentacija u učenju, opremljenosti škole digitalnim medijima i upotrebe digitalnih medija $u$ kvaliteti predmetne nastave osnovnog obrazovanja (ISCED razina 2). Istraživanje je provedeno s učenicima sedmih i osmih razreda $(N=432)$ osnovnih škola u Gradu Zagrebu i Splitsko-dalmatinskoj županiji. Uz demografska obilježja učenika, opremljenost škole pojedinim digitalnim medijima, podaci su prikupljeni Upitnikom ciljnih orijentacija u učenju (CSRL), Upitnikom implementacije digitalnih medija u nastavi (TIQ) i Upitnikom kvalitete nastave (SPOCQ). Pokazalo se da su demografska obilježja učenika, njihove ciljne orijentacije učenja, opremljenost škole digitalnim medijima i motivacija upotrebe digitalnih medija značajni prediktori učeničke procjene kvalitete nastave, s time da najveći dio varijance objašnjavaju ciljne orijentacije učenja s naglaskom na usmjerenost na učenje. S obzirom na to vidljivo je da za kvalitetu nastave u digitalno doba nije najznačajnija upotreba digitalnih medija, već su najznačajnije ciljne orijentacije, tj. motivacija za učenje. U radu su objašnjeni usporedba s teorijskim polazištima i implikacije dobivenih rezultata.

Ključne riječi: ciljne orijentacije, digitalni mediji, kvaliteta nastave, osnovna škola, učenici. 